\title{
KEY FACTORS FOR THE DEVELOPMENT OF ELECTRO MOBILITY
}

\author{
DOMINIK KOLZ \& MARCEL SCHWARTZ \\ Institute for Industrial Management at RWTH, Aachen University, Germany
}

\begin{abstract}
Electro mobility provides the basis for a fundamental, worldwide change when it comes to individual mobility. This change goes far beyond just using vehicles with an electric engine. The transformation also holds the opportunity of developing and providing new kinds of service solutions that can determine the success of electro mobility significantly. A good service offering can function as a mediator between the technology on the one hand and the market and its potential buyers on the other hand. So far, the number of sold and used electric vehicles in the world does not meet the expectations as potential buyers hesitate to purchase the cars. Currently existing scientific work researching the development of electro mobility is primarily focused on technological aspects of emobility, such as the range electric vehicles can reach - an in-depth analysis of all the other influence factors effecting the development and success of electro mobility does not exist yet. It is necessary, however, in order to not only implement suitable service solutions successfully but also influence the development of electro mobility in a positive way. Specific criteria that affect the success of e-mobility can only be met if they are clearly identified. Therefore, the aim of this research paper is to identify relevant key influence factors for the future development of electro mobility and researching which requirements need to be considered in order to increase the acceptance of electric mobility.

Keywords: electro mobility, e-mobility, e-cars, electric vehicle, environment, cars.
\end{abstract}

\section{INTRODUCTION}

"Renew the definition of what an automobile is" - this is the guideline principle of the governmental programme focussing on the development of electro mobility. It underlines how fundamental this new technology is, which is set to change the form of our mobility in the future drastically in the framework of mobility turning point [1]. However, despite of governmental substitution, financing programs and technological improvements, the general demand of the society for electric vehicles still does not meet the general expectations. In the beginning of 2017, the total number of electric vehicles in Germany included 34.022 electricdriven cars and another 165,405 hybrid-driven vehicles [2]. Although electric vehicles only make up a very small share of the overall total of cars of 62.6 million in Germany [2], a record growth of 11.624 new e-vehicle registrations was recorded in the first quarter of 2017 [3]. However, international comparison shows that Germany remains far behind China, the USA, Norway and France when it comes to the amount of newly registered electricity-driven vehicles. Almost half of the approx. 750,000 newly registered electric cars worldwide in 2016 were registered in China [4], while Germany accounted for less than 5 percent [3].

For many of the potential electro vehicle buyers who were surveyed in a survey conducted by FIR in Germany and the Netherlands, the overall short range of electric vehicles is a significant reason to refrain from purchasing an electric car for personal use [5]. This shows that it is a fundamental requirement for the success of electro mobility to meet the customers' demands. In this context of meeting the buyers' demand, services can play an important role: Service solutions such as car sharing can increase the customer proximity and decrease the still current technological deficit of a short range [6]. 
This paper aims to identify all factors that influence the development of electro mobility. This will include not only technological but also service offerings. To begin with, influence areas are identified. Afterwards, influencing factors that have a positive or negative effect on the development of electro mobility are determined for each of these areas. As a last step, particularly relevant factors, so-called key factors, are selected from the influencing factors identified before. The knowledge on key factors is the basis for a broad understanding of the topic and makes it possible to develop measures of action that can support the development of electro mobility.

\section{STATE OF RESEARCH}

A large number of scientific papers exist which examine influencing parameters of electro mobility. These factors can be grouped into categories because of similarities. Factors such as the demographic development, development of income and overall lifestyle can be clustered, for example, and added to the category "development of the society". By doing this, the large number of influencing factors is significantly reduced into nine clearly defined categories. This makes it easier to organise and manage the influencing variables and adds to their differentiation.

Based on a broad literature review, the following categories can be identified: Charging infrastructure | technical progress | political measures | overall operating costs traffic behaviour $\mid$ society change $\mid$ mobility options | resource availability | value-added system.

The first four of these categories are mentioned in almost all of the reviewed scientific research papers. Based on these findings, they can be identified as common influencing factors with a presumably strong impact on the development of electro mobility. The categories charging infrastructure and technological progress focus on technological specifics such as the allowed degree of discharge or the progress of the battery technology. The categories overall operating costs, resource availability and added value system, however, all refer to economic aspects. Only the categories traffic behaviour and mobility options refer to areas where actual services apply and can function as a connection between technology and economy - yet only a few of the papers actually describe services as a relevant factor for the development of electro mobility (e.g. in the area of information and communication technology). In summary, it becomes clear that past and current scientific work does not consider the influence of services to a sufficient level. This is a disadvantage if the aim is to look at the development of electro mobility from a holistic point of view. An analysis of all factors for the future development of the electro mobility is still missing as well as one that focusses on both the technological as well as the service aspects to a greater level.

\section{METHOD OF PROCEDURE}

In order to close the discovered gap in research, this paper is structured as follows: To begin with, influence factors are identified. Afterwards, they are further divided into general influence and key influence factors, also simply referred to as key factors. To do so, the influencing analysis based on REIBNITZ is used [7]. This analysis consists of four steps: First, the field of topic is defined and, if required, separated into numerous sub-areas [7]. Second, influence areas are defined for each of these fields based on an in-depth literature research. These influence areas function as a logical categorisation of the individual influencing factors, which are defined in the following step number three: Identification of influencing factors. Influencing factors are parameters that provide information about the current situation of electro mobility in a specific area or country. As such, they also define 


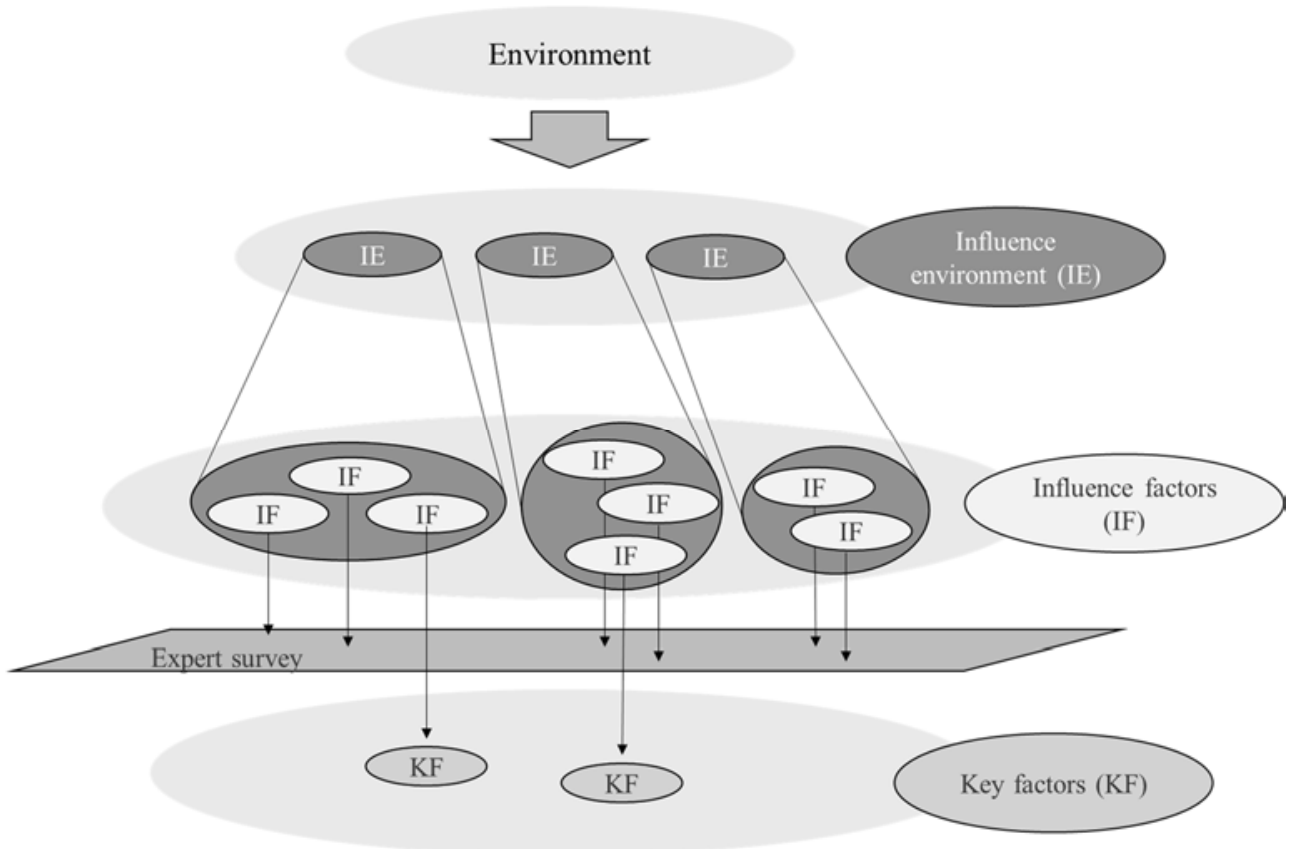

Figure 1: Schematic presentation of the methodological procedure.

the development of electro mobility not only when they change, but also when their change has a dynamic effect on other factors. In order to increase the transparency of the large number of influence factors, they are further specified and separated in general influence factors and key factors during the last step of the analysis, step four. The overall method of procedure is schematically visualised in Fig. 1.

\section{RESULTS}

\subsection{Distinction of the research field}

The term electro mobility conventionally stands for all vehicles driven by a fully or partially electric engine [8]. In this paper, this research field also includes everything else that is included in the electro mobility environment - only if the strict definition of the term is expanded, service solutions regarding electro mobility can be discussed as well. The following quote summarises this broader definition:

"E-mobility (electric mobility) is a highly connective industry which focuses on serving mobility needs under the aspect of sustainability with a vehicle using a portable energy source and an electric drive that can vary in the degree of electrification" [9].

Within this research area, it needs to be differentiated between the global and the local surroundings of electro mobility. Influence areas and factors that belong to the global surrounding tend to have an active impact on their environment. However, they can only be influenced and adjusted to a very limited extent and therefore need to be considered as externally predefined. In contrast to this, influencing factors that belong to the local surrounding of electro mobility are mostly passive, they are adjustable to a much greater 
extent and have greater differences among each other than influencing factors within the global surrounding [7], [10]-[12].

\subsection{Identification of influence areas}

The following paragraph explains influence areas of the global and local surrounding of electro mobility. To do so, elements of the so-called STEP-analysis are used to identify influence areas that belong to the global surrounding [13]. Additionally, previously published environmental analyses covering a similar topic as the present research paper were sighted.

The STEP-analysis is most commonly used in strategic management to assess the global business environment. This method separates a business environment into political, economic, socio-cultural and technological factors [13]. In the past, different authors have complemented the original model and added ecological components to it [14]. Based on this further developed analysis model, five global influence areas of electro mobility can be distinguished. Table 1 provides a short definition of each of these.

To identify local influence areas, numerous scientific publications are sighted. They list the technical state, the usage, the industry (automobile producers), the energy industry and value-added services as important areas of electro mobility [10], [15]. Furthermore, the characteristics of the market form another area of influence, which is described in various publications [16], [17]. Overall, six local electro mobility areas of influence were found in the scientific research literature. They are explained briefly in Table 2.

Table 1: Global influence areas of electro mobility.

\begin{tabular}{|l|l|}
\hline Global influence area & Description \\
\hline Economy & $\begin{array}{l}\text { Immediate competition for electro mobility and economic } \\
\text { development }\end{array}$ \\
\hline Technology & Incremental or radical technological advances in electro mobility \\
\hline Politics & $\begin{array}{l}\text { General and specific policy framework for electro mobility (e.g. } \\
\text { political stability or legislation) }\end{array}$ \\
\hline Society & $\begin{array}{l}\text { Social change in society, e.g. with regard to the demographic } \\
\text { composition or values }\end{array}$ \\
\hline Environment & $\begin{array}{l}\text { Environmental aspects of the conservation of the natural } \\
\text { environment (e.g. greenhouse gas emissions) }\end{array}$ \\
\hline
\end{tabular}

Table 2: Local influence areas of electro mobility.

\begin{tabular}{|l|l|}
\hline Local influence area & Description \\
\hline Technical state & Technological features of an electric vehicle \\
\hline Usage & Use of electric vehicles \\
\hline Value-added services & $\begin{array}{l}\text { Services that influence the attractiveness or functionality of } \\
\text { electro mobility }\end{array}$ \\
\hline Automotive Manufacturers & $\begin{array}{l}\text { Behaviour of automotive manufacturers in the context of } \\
\text { electro mobility }\end{array}$ \\
\hline Energy economy & $\begin{array}{l}\text { Behaviour of the actors in the energy industry in the context } \\
\text { of the electro mobility }\end{array}$ \\
\hline Market characteristics & Competition and co-operation between market participants \\
\hline
\end{tabular}




\subsection{Identification of influencing factors}

In order to identify influence factors for each of the influence areas, further in-depth literature research is carried out. Potential influence factors are not only evaluated by the frequency of their mentioning but also by their degree of differentiation, their degree of integration and their research area as well as their comprehensibility and their precision. If two factors show a significant similarity and refer to the same reference aspect, they are combined and condensed to one influence factor: Governmental subsidies, for example, refer to the same aspect of financial support as the financial aid based on the so-called scrapping bonus or similar financing concepts. Because of this, they are not listed as individual influence factors but instead summarised by using the superordinate influence factor governmental substitution.

Overall, 55 influence factors can be identified and clearly distinguished from another. Amongst these are 29 global and 26 local factors. Only the six global factors total cost of ownership, competition, sensitisation, infrastructure, safety and function integration show noticeably similarities to a couple of local influence factors, namely the factors costs, increased competition, level of information, charging infrastructure, safety and smart grid.

Table 3 summarises the identified global and local influence factors. They also show to which global/local influence area the factors belong. Factors that belong to both surroundings are highlighted in italics.

Table 3: Areas and factors of influence.

\begin{tabular}{|l|l|}
\hline Global area of influence & Global factors of influence \\
\hline Economy & $\begin{array}{l}\text { Oil price, electricity price, battery price, total cost of } \\
\text { ownership, exchange rate, competition }\end{array}$ \\
\hline Technology & $\begin{array}{l}\text { Drive technology, battery technology, infrastructure, } \\
\text { integration of functions, security }\end{array}$ \\
\hline Politics & $\begin{array}{l}\text { Governmental funding, regulation, taxes and charges, laws, } \\
\text { energy \& climate policy, standardisation }\end{array}$ \\
\hline Society & $\begin{array}{l}\text { Demographic change, awareness, value change, user } \\
\text { acceptance, mobility behaviour, urbanisation, } \\
\text { metropolisation }\end{array}$ \\
\hline Environment & $\begin{array}{l}\text { Sustainability, Climate Change, Environmental Awareness, } \\
\text { Resource Availability, Recycling }\end{array}$ \\
\hline Local area of influence & Local factors of influence \\
\hline Technical state & $\begin{array}{l}\text { Range, charging concepts, charging time, lightweight } \\
\text { design, safety }\end{array}$ \\
\hline Usage & $\begin{array}{l}\text { Available information, everyday life, costs, image, } \\
\text { visibility, commercial use }\end{array}$ \\
\hline Value-added services & $\begin{array}{l}\text { Financing offers, ICT-based services, multimodal concepts, } \\
\text { workshop availability, private car sharing, long-time battery } \\
\text { services }\end{array}$ \\
\hline Automobile manufacturers & Model diversity, stand-alone platform, service concepts \\
\hline Energy industry & Charging infrastructure, Renewable energy, Smart Grid \\
\hline Market characteristics & $\begin{array}{l}\text { Increased competition, co-operation, market penetration of } \\
\text { electric vehicles }\end{array}$ \\
\hline
\end{tabular}




\subsection{Selection of key factors}

Key factors are selected from the pool of previously identified influence factors with the help of an online survey. In order to obtain valuable and objective results, the survey was strictly aimed at experts of the industry. Experts are generally referred to as persons with a high level of expertise regarding a particular scientific topic or research field [21]. One of the criteria of selecting an expert for the survey was that the expert needed to pursue a professional activity in the overall field of electro mobility. Experts with a scientific background as well as those with a practical background were among the survey participants in order to balance out any influence on the results that a large number of professional experts may have.

The questionnaire used for this survey was put together with the online tool 2ask, which is very easy to use and user-friendly [18]. The selected experts answered the questions anonymously, by themselves and within a predetermined length of time. This chosen research method has advantages as well as disadvantages: The participating experts can benefit from a high level of anonymity, a flexible time schedule and a high level of usability [19]. It is also beneficial that the digital questionnaire can be analysed automatically. Disadvantages of this scientific method include the possibility of misunderstanding of questions and the absence of a responsible person during the survey that could help the survey participants. However, the risk of a problem like this can be limited by using extra care when wording the questions.

The questionnaire includes one question for each of the identified influence factors (again, factors that can be found in the global as well as the local surrounding of electro mobility are summarised and referred to as one factor). Each question includes the name of the influence factor as well as its definition in the context of electro mobility. By providing a clear definition of the factors, misunderstandings shall be prevented. In the questionnaire, the experts are asked to rate the relevance of a factor for the development of electro mobility. To do so, an ordinal scale is used [20]. The scale consists of the following qualitative options: the influence is (1) very low, (2) low, (3) high or (4) very high. Each of these rating options is given a numerical value in order to make the analysis of the survey results easier. Experts can also decide to abstain from answering a question if they wish to do so.

The results of the expert survey are analysed and evaluated by calculating the mean value of the answers that were given. By doing so, it can be analysed which influence factors appear to be key factors [22]. Table 4 shows the identified key factors, classified according to the ranked mean values of the expert evaluations. The assignment of the factors to the global or local environment is indicated by colour.

Table 4: Influence factors of electro mobility.

\begin{tabular}{|l|c|l|c|}
\hline Influence factor & Average & Influence factor & Average \\
\hline 1. Battery price & 3,72 & 9. Charging concepts & 3,39 \\
\hline 2. Range & 3,66 & 10. Standards & 3,38 \\
\hline 3. User acceptance & 3,65 & 11. Charging infrastructure & 3,31 \\
\hline 4. Costs & 3,57 & 12. Everyday suitability & 3,28 \\
\hline 5. Charging time & 3,53 & 13. Oil price & 3,28 \\
\hline 6. Governmental funding & 3,53 & 14. New service concepts & 3,23 \\
\hline 7. Battery technology & 3,53 & 15. Safety & 3,22 \\
\hline 8. Energy and climate policy & 3,52 & 16. Energy price & 3,17 \\
\hline
\end{tabular}


The following list contains definitions for each key factor. These may differ from the general understanding of the respective term.

1. Battery price describes the average price of an accumulator depending on its capacity $[€ / \mathrm{kWh}]$.

2. Range describes the distance that electric vehicles can travel on average with a fully charged battery within real driving conditions.

3. User acceptance describes the decision to accept an innovation by the user.

4. Costs describe the lifecycle costs of electric vehicles (e.g. acquisition and operating costs)

5. Charging time is the duration to achieve a full battery charge.

6. Governmental funding describes the financial support for the dissemination of electro mobility through public funds.

7. Battery technologies describe the chemical composition of various battery technologies (e.g. lithium-ion accumulators).

8. Energy and climate policy describes the measures dealing with the topics of energy and climate.

9. Charging concepts describe the manner of recharging the battery of an electric vehicle (e.g. inductive charging).

10. Standardisation describes the unification of standards for the creation of common standards in the context of electro mobility (e.g. uniform charging connectors).

11. Charging infrastructure describes the availability of publicly available charging points.

12. Everyday suitability describes the integration capability of the electric vehicle into the everyday life of a user.

13. Oil price describes the price of crude oil.

14. New service concepts describe services offered by market players for users of electric vehicles (e.g. car sharing).

15. Safety describes the protection against dangers and risks that can occur in the everyday handling of electro mobility (e.g. flaming the battery).

16. Energy price describes the costs of the generation of electricity, grid use as well as taxes and charges for electrical energy.

The two-highest ranked key factors, battery price and range, as well as the factors of charging time and battery technology, show that the success of electro mobility is decisively dependent on advances in battery technology. In addition, also the life cycle costs (costs) as well as political measures (governmental funding, energy and climate policy) are essential for the development of electro mobility. Furthermore, the expansion of the charging infrastructure as well as advancements in charging technologies (charging concepts, standardisation) are success factors for electric mobility. In addition, services can make an important contribution to the success of electro mobility through service platforms that promote standardisation or through new service concepts that increase the user acceptance.

\section{CONCLUSIONS}

The identified key factors show that services are of high relevance for the development of electro mobility. They form an integral part of electro mobility and are crucial to their success. A wide range of applications such as innovative usage models, technology accompanying services and infrastructure services enable a comprehensive design of electric mobility and influence the entire life cycle of electric vehicles [6]. It is only by means of 
services that the development to a mobility driven society that uses instead of possesses mobility is feasible [23]. The results of this work are used as part of the DELFIN project to develop future scenarios for electro mobility from 2020 onwards. Therefore, the identified key factors are initially compared with one another in order to be able to evaluate and represent interactions between the factors. Afterwards, a consistency analysis is carried out and used to develop future scenarios for the development of electro mobility. These scenarios determine which future combinations of positive, negative or trend developments of the key factors are consistent. The knowledge of these scenarios, as well as the knowledge of the key factors, allows the derivation of plans for action for stakeholders, in order to be aligned with the optimal development of the electro mobility.

\section{ACKNOWLEDGEMENTS}

The DELFIN project "Services for Electro mobility: Promoting Innovation and User Orientation", which runs from 2013 to 2018, aims to develop strategies for services in the value-added system of the electric mobility sector. The project with the promotion code 02K12A 000/001/002 is funded by the German Federal Ministry of Education and Research (BMBF) as a subproject as part of the the program "Service Innovations for Electro mobility".

\section{REFERENCES}

[1] Lindemann, K. \& Muhle, C., Mobilität und Wachstum. Vorschläge der Automobilindustrie für die 19. Legislaturperiode. Hg. v. Verband der Automobilindustrie e.V. (VDA), 2017.

[2] Kraftfahrt-Bundesamt: Bestand - Jahresbilanz des Fahrzeugbestandes am 1. Januar 2017, https://www.kba.de/DE/Statistik/Fahrzeuge/Bestand/b_jahresbilanz.html. Accessed on: 10 Aug. 2017.

[3] Datenservice Erneuerbare Energien. Unter Mitarbeit von Thomas Nieder und Andreas Püttner. Hg. v. Zentrum für Sonnenenergie- und Wasserstoff-Forschung BadenWürttemberg (ZSW), https://www.zsw-bw.de/mediathek/datenservice.html\#c6700. Accessed on: 10 Aug. 2017.

[4] McKinsey \& Company: Electric Vehicle Index, https://www.mckinsey.de/ elektromobilitaet. Accessed on: 10 Aug. 2017.

[5] Schwartz, M. \& Kolz, D., DELFIN. Dienstleistungen für Elektromobilität. Förderung von Innovation und Nutzerorientierung. Fallstudie Aachen - Amsterdam. p. 20 f., 2016.

[6] Beverungen, D., Fabry, C. \& Ganz, W., Dienstleistungsinnovationen für Elektromobilität. Märkte, Geschäftsmodelle, Kooperationen. Hg. v. Daniel Beverungen, http://www.elektromobilitaet-dienstleistungen.de/wp-content/ uploads/2015/02/Dienstleistungsinnovationen-fuer-Elektromobilitaet_MaerkteGeschaeftsmodelle-Koop_2015.pdf. Accessed on: 10 Aug. 2017.

[7] Reibnitz, U., Szenario-Technik. Instrumente für die unternehmerische und persönliche Erfolgsplanung. 2. Auflage. Wiesbaden, s.l.: Gabler Verlag, http://dx.doi.org/10.1007/978-3-663-15720-5. Accessed on: 10 Aug. 2017.

[8] Allianz für nachhaltige Beschaffung. Leitfaden Elektromobilität. Beschaffung von Elektro- und Hybridfahrzeugen. Hg. v. Allianz für nachhaltige Beschaffung, 2016.

[9] Karlsruhe Institute of Technology, Holistically Defining E-Mobility. A Modern Approach to Systematic Literature Reviews. In: Frank J. Fabozzi und Vinod Kothari (Hg.): Introduction to securitization. Hoboken, N.J: John Wiley \& Sons (The Frank J. Fabozzi series), S. 1-12, https://paperfinderapp.com/holisticallydefininge-mobility. pdf. Accessed on: 10 Aug. 2017. 
[10] Schuh, G., Stich, V. \& Ansorge, B., Smart Wheels: mobil im Internet der Energie. Aachen: FIR e.V. an der RWTH Aachen (Edition Forschung, 10), 2013.

[11] Mißler-Behr, M., Methoden der Szenarioanalyse. Wiesbaden, s.l.: Deutscher Universitätsverlag (DUV Wirtschaftswissenschaft), http://dx.doi.org/10.1007/ 978-3-663-14585-1. Accessed on: 10 Aug. 2017.

[12] Fink, A., Schlake, O. \& Siebe, A., Erfolg durch Szenario-Management. Prinzip und Werkzeuge der strategischen Vorausschau. 2. Aufl. Frankfurt/Main: Campus-Verlag, 2001.

[13] Aguilar, F., Scanning the Business Environment: New York: Macmillan, 1967.

[14] Pearce, J. \& Robinson, R., Strategic Management: Formulation, Implementation, and Control. 11 ${ }^{\text {th }}$ Edition. Boston: McGraw-Hill, 2009.

[15] E-Mobility: Lange Fahrt zum Milliardengeschäft. Der Schlüssel zu erfolgreichen Geschäftsmodellen ist innovative Vernetzung. A.T. Kearney Inc. Düsseldorf., http://www.atkearney.de/documents/856314/1214952/EB_EMobility_Lange_Fahrt_z um_Milliardengeschaeft.pdf/9149a4ad-c338-4207836dc55f4c0e5a93,2011. Accessed on: 10 Aug. 2017.

[16] Teichmann, G. A., Trützschler, J. \& Hahn, C., Elektromobilität. Normen bringen die Zukunft in Fahrt, 2012.

[17] Mayer, C., Strukturierung und Bewertung von Dienstleistungskonzepten aus dem Bereich der Elektromobilität, Stuttgart, 2014.

[18] 2ask, Ihr Online-Umfrage-Tool. 2015. http://www.2ask.de. Accessed on: 10 Aug. 2017.

[19] Brandenburg, T., Thielsch, M. \& Mehlich, P., Praxis der Wirtschaftspsychologie. Themen und Fallbeispiele für Studium und Anwendung. Münster: Monsenstein und Vannerdat (MV-Wissenschaft), 2009.

[20] Lamprecht, M. \& Stamm, H. \& Ruschetti P., Wissenschaftliches Arbeiten. Ein Leitfaden für Diplom- und Semesterarbeiten. Hg. v. Gesellschaft zur Förderung der Sportwissenschaften an der ETH Zürich. ETH Zürich. Zürich, http://www.lsweb.ch/fileadmin/lsweb-dateien/publikationen/GFS-Methodologie.pdf. Accessed on: 10 Aug. 2017.

[21] Bogner, A., Littig, B. \& Menz, W., eds. Das Experteninterview. VS Verlag für Sozialwissenschaften, 2002.

[22] Stier, W., Empirische Forschungsmethoden. Berlin: Springer (Springer-Lehrbuch), 1999.

[23] Mit der Verkehrswende die Mobilität von morgen sichern. 12 Thesen zur Verkehrswende. Hg. v. Agora Verkehrswende, https://www.stiftung-mercator.de/ media/downloads/3_Publikationen/Agora_Verkehrswende_12_Thesen_zur_Verkehrs wende_Publikation_Maerz_2017.pdf. Accessed on: 10 Aug. 2017. 